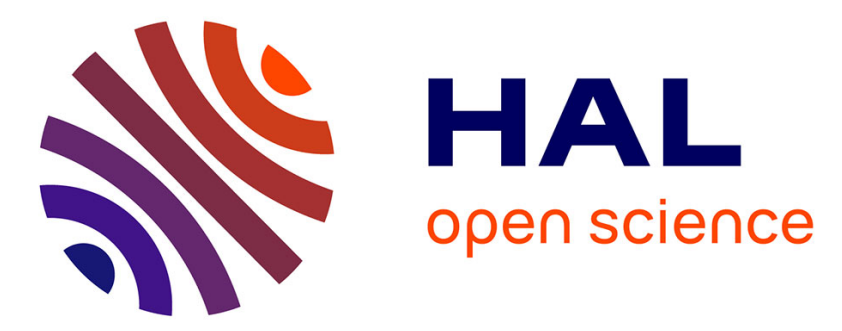

\title{
-associated breast and ovarian cancer risks in Poland: no association with commonly studied polymorphisms
}

\author{
Anna Jakubowska, Jacek Gronwald, Janusz Menkiszak, Bohdan Górski, \\ Tomasz Huzarski, Tomasz Byrski, Aleksandra Toloczko-Grabarek, Michael \\ Gilbert, Lutz Edler, Marc Zapatka, et al.
}

\section{To cite this version:}

Anna Jakubowska, Jacek Gronwald, Janusz Menkiszak, Bohdan Górski, Tomasz Huzarski, et al.. -associated breast and ovarian cancer risks in Poland: no association with commonly studied polymorphisms. Breast Cancer Research and Treatment, 2009, 119 (1), pp.201-211. 10.1007/s10549-0090390-5 . hal-00535356

\section{HAL Id: hal-00535356 https://hal.science/hal-00535356}

Submitted on 11 Nov 2010

HAL is a multi-disciplinary open access archive for the deposit and dissemination of scientific research documents, whether they are published or not. The documents may come from teaching and research institutions in France or abroad, or from public or private research centers.
L'archive ouverte pluridisciplinaire $\mathbf{H A L}$, est destinée au dépôt et à la diffusion de documents scientifiques de niveau recherche, publiés ou non, émanant des établissements d'enseignement et de recherche français ou étrangers, des laboratoires publics ou privés. 


\title{
$B R C A 1$-associated breast and ovarian cancer risks in Poland: no association with commonly studied polymorphisms
}

\author{
Anna Jakubowska · Jacek Gronwald · Janusz Menkiszak · Bohdan Górski · \\ Tomasz Huzarski · Tomasz Byrski · Aleksandra Tołoczko-Grabarek • \\ Michael Gilbert · Lutz Edler · Marc Zapatka · Roland Eils · Jan Lubiński · \\ Rodney J. Scott $\cdot$ Ute Hamann
}

Received: 23 March 2009/Accepted: 24 March 2009/Published online: 10 April 2009

(C) Springer Science+Business Media, LLC. 2009

\begin{abstract}
Polymorphisms in genes involved in DNA repair, steroid hormone biosynthesis/metabolism/signaling, folate metabolism as well as cell growth are prime candidates for possible associations with breast and ovarian cancer risk in women with an inherited predisposition. We investigated 29 polymorphisms in 20 genes encoding key proteins of the above four biological pathways for their breast and ovarian cancer risk modifying effect in Polish women harboring $B R C A 1$ founder mutations. Of the analyzed genes, ERCC2, XRCC1, XRCC2, XRCC3 and Lig4 participate in DNA repair, TP53 in cell cycle check point control, AIB1, AR, COMT, CYP11A1, CYP17A1, CYP19A1, $H S D 17$ and $P G R$ in steroid hormone biosynthesis/metabolism/signaling, TYMS in folate metabolism and HER2, IL6, $L R P 1, T G F B$ and TGFBRI affect cell growth. Using validated methods, we genotyped 319 breast cancer cases, 146 ovarian cancer cases and 290 unaffected controls, all of whom harbored one of three causative mutations in BRCAl.
\end{abstract}

Electronic supplementary material The online version of this article (doi:10.1007/s10549-009-0390-5) contains supplementary material, which is available to authorized users.

A. Jakubowska · J. Gronwald · J. Menkiszak · B. Górski ·

T. Huzarski · T. Byrski · A. Tołoczko-Grabarek · J. Lubiński

Pomeranian Medical University, UL Polabska 4, 70-111

Szczecin, Poland

\footnotetext{
A. Jakubowska $\cdot$ M. Gilbert · U. Hamann $(凹)$

German Cancer Research Center, Molecular Genetics of Breast Cancer, B055, Im Neuenheimer Feld 580, 69120 Heidelberg, Germany

e-mail: u.hamann@dkfz-heidelberg.de

J. Menkiszak

Department of Surgical Gynecology and Gynecological

Oncology of Adults and Adolescents, ul. Powstancow Wlkp. 72 ,

70-111 Szczecin, Poland
}

Our results revealed no association of any of the investigated polymorphisms with BRCAl-associated breast or ovarian cancer risk. Thus, it appears that these polymorphisms do not influence disease risk in Polish women carrying one of the three common $B R C A l$ founder mutations.

Keywords BRCAl - Breast cancer - Ovarian cancer . Polymorphism $\cdot$ Modifying gene

\section{Introduction}

Breast and ovarian cancers are a leading cause of morbidity and mortality in women worldwide. The major inherited susceptibilities to these cancers are germline mutations in either $B R C A 1$ or $B R C A 2$ [1]. It has been estimated that $B R C A 1$ mutation carriers have high average lifetime risks of developing breast and ovarian cancers [2]. Notwithstanding, there are substantial differences in the penetrance

\author{
L. Edler \\ German Cancer Research Center, Division of Biostatistics, \\ Im Neuenheimer Feld 280, 69120 Heidelberg, Germany \\ M. Zapatka $\cdot$ R. Eils \\ German Cancer Research Center, Division of Theoretical \\ Bioinformatics, Im Neuenheimer Feld 580, 69120 Heidelberg, \\ Germany \\ R. J. Scott \\ Discipline of Medical Genetics, School of Biomedical Sciences, \\ University of Newcastle and the Hunter Medical Research \\ Institute, Lookout Road, Newcastle, NSW 2305, Australia
}


of disease both within and between families that is best explained by genetic and/or shared environmental factors affecting the risk of breast and ovarian cancers [3].

Both, breast and ovarian cancers are hormonally influenced diseases that point to the importance of mechanisms underlying steroid biosynthesis, metabolism and signaling as well as cell growth. A number of reports have suggested that polymorphisms in steroid receptors and some of their downstream effectors may be associated with an altered risk of disease [4-13]. However, these reports are controversial, since conflicting results have also been published [14-21]. The relationship between aberrant estrogen metabolism and increased levels of DNA damage implicate the various DNA repair pathways that are invoked as a result of an increased level of free-radicals in the target tissue. Excessive levels of estrogen are associated with increased cell division, which requires a large pool of purines and pyrimidines for rapid DNA synthesis. The supply of methionine is crucial for pyrimidine synthesis, as decreased levels are associated with base mis-incorporation, which ultimately results in an increased likelihood of not only genetic errors, but also invocation of DNA repair enzymes.

While a large number of previous studies have reported associations of various polymorphic variants in genes involved in DNA repair, steroid hormone biosynthesis/ metabolism/signaling, folate metabolism and cell growth with sporadic breast or ovarian cancer risk [4-33], little data on the potential role of these genetic factors as modifiers of hereditary disease risks have been published [3442]. Therefore, we investigated whether variants in genes of these four regulatory pathways may act as modifiers of breast and ovarian cancer risk in Polish women carrying one of the three common BRCAl founder mutations (4153delA, 5328insC and C61G) [43, 44]. Genotyping analysis was performed in 319 breast cancer cases, 145 ovarian cancer cases and 290 controls.

\section{Materials and methods}

Study participants

The Pomeranian cancer registry contained clinical and epidemiological data from 1,940 individuals carrying one of the three common Polish BRCAl founder mutations, 5382insC, $300 \mathrm{~T}>\mathrm{G}$ and 4153delA. Mutation carriers were selected from families with at least one breast cancer diagnosed before 50 years of age or ovarian cancer at any age or with strong history of breast and/or ovarian cancer. All clinical data have been verified from medical records and were collected from 1997 to 2002. A self-administered questionnaire was used to collect information on potential epidemiological risk factors.

From the registered $B R C A 1$ carriers, 755 female $B R C A l$ mutation carriers for whom DNA samples were available319 breast cancer cases, 146 ovarian cancer cases and 290 unaffected controls-were included in this study. All study participants were of Polish origin and resided in Poland. They were considered as breast cancer cases, if they were diagnosed with an invasive primary breast cancer and had not undergone prophylactic mastectomy or adnexectomy prior to the age of breast cancer diagnosis and as ovarian cancer cases, if they were diagnosed with invasive primary ovarian cancer (excluding borderline ovarian carcinoma) and had not undergone prophylactic mastectomy, adnexectomy or tubal ligation prior to the age of ovarian cancer diagnosis. They were considered as controls for breast cancer cases, if they were unaffected by breast cancer, in situ breast carcinoma or any other type of cancer and had not undergone prophylactic mastectomy or adnexectomy and as controls for ovarian cancer cases if they were unaffected by ovarian cancer or any other type of cancer and had not undergone prophylactic mastectomy, adnexectomy or tubal ligation.

The number of subjects in the various subgroups, the median ages of breast and ovarian cancer cases at the time of diagnosis and the median ages of controls at the time of interview are shown in Table 1 . The research was approved by the Ethics Committee of Pomeranian Medical University in Szczecin, Poland and all participants gave informed consent prior to enrolling in the study. All women received genetic counseling prior to and at the provision of their test results.

\section{Genetic analyses}

Twenty-nine polymorphisms in 20 genes involved in DNA repair, steroid hormone biosynthesis/metabolism/signaling, folate metabolism and cell growth were genotyped. The genes, variants under investigation and genotyping methods are given in Supplementary Tables 1 and 2 .

Genomic DNA was isolated from peripheral blood leukocytes according to Lahiri and Schnabel [45]. Seventeen restriction fragment lengths polymorphisms (RFLPs), six insertion/deletion polymorphisms and six repeat polymorphisms were genotyped by PCR-based fragment analyses using the $\mathrm{CEQ}^{\mathrm{TM}} 8000$ Genetic DNA Analysis System (Beckman Coulter, Krefeld, Germany) and/or ethidium bromide-stained agarose gels (Sigma-Aldrich, Steinheim, Germany), which were scored by UV visualization. Primer sequences, PCR and genotyping conditions are presented in Supplementary Table 2. CYP17A1 -34T $>$ C, CYP19A1 15210(TTTA)n, CYP19A1 15262delCTT and COMT $1222 \mathrm{G}>\mathrm{A}$ were genotyped as described earlier [46]. 
Table 1 Study groups, median ages of cases at diagnosis of breast and ovarian cancers and of controls at the time of interview

\begin{tabular}{llll}
\hline No. of cases and controls & $\begin{array}{l}\text { Risk factor data } \\
\text { available }\end{array}$ & $\begin{array}{l}\text { Median age of cases } \\
\text { at cancer diagnosis } \\
\text { in years (range) }\end{array}$ & $\begin{array}{l}\text { Median age of controls } \\
\text { at the time of interview } \\
\text { in years (range) }\end{array}$ \\
\hline $\begin{array}{l}\text { Breast cancer cases/controls } \\
319 / 290 \text { (total) }\end{array}$ & Yes & $41(22-74)$ & $44(18-85)$ \\
$232 / 225$ & No & $41(24-74)$ & $44(18-85)$ \\
$87 / 65$ & & $39(22-56)$ & $48(34-75)$ \\
Ovarian cancer cases/controls & & & $47(25-75)$ \\
$146 / 280$ (total) & Yes & $46(25-71)$ & $44(18-85)$ \\
$85 / 215$ & No & $48(27-75)$ & $48(34-75)$ \\
$61 / 65$ & & &
\end{tabular}

a Two-hundred and eighty of the controls were used as controls for both breast and ovarian cancers
14 was selected using maximal selected rank statistics [47], yielding the categories $\leq 14 / \leq 14, \leq 14 />14$ and $>14 />14$. For CYP11A1 (AAAAT)n, the categories were 4/4, 4/6, 6/6, $8 /$ any and others [26]. Allele frequencies of repeat polymorphisms between cases and controls were compared using Pearson's chi square test. For each SNP, statistical modeling was performed using unconditional logistic regression to assess the predicted power of the study. Bonferroni correction was used to account for multiple testing and a two-tailed $P$ value $<0.0017$ was considered statistically significant.

\section{Results}

The distribution of selected cancer risk factors including year of birth, age at menarche, age at first live birth, parity, duration of breastfeeding, smoking, BMI and BRCA1 mutation was similar between breast and ovarian cancer cases and their corresponding controls (Table 2).

In total, 755 study participants were genotyped at 29 polymorphisms in 20 genes, which included eleven variants in five DNA repair genes (ERCC2, XRCC1, XRCC2, $X R C C 3$ and Lig4) and the cell cycle check point control gene (TP53), five variants in five growth factor and receptor genes (HER2, IL6, LRP1, TGFB1 and TGFBR1), two variants in the thymidylate synthetase gene (TYMS) and eleven variants in eight genes associated with steroid hormone biosynthesis, metabolism and signaling (AIB1, AR, COMT, CYP11A1, CYP17A1, CYP19A1, HSD17B1 and $P G R$ ).

The distribution of the genotype frequencies among breast and ovarian cancer cases and their respective controls is shown in Table 3. Three polymorphisms, XRCC3 204(GT)n, COMT 1222G $>$ A and CYP11Al (AAAAT) $n$ appeared to be related to disease expression in ovarian cancer $\left(\mathrm{OR}_{\text {crude }} 2.24,95 \%\right.$ CI 1.02-4.92 $\mathrm{OR}_{\text {crude }} 1.85,95 \%$ CI $1.01-3.48$ and $\mathrm{OR}_{\text {crude }} 0.54,95 \%$ CI $0.31-0.95$, respectively). Two other polymorphisms, TP53 441G $>\mathrm{C}$ and TGFB $1-1349 \mathrm{C}>\mathrm{T}$, were associated with an increased breast cancer risk after adjustment for potential risk factors $\left(\mathrm{OR}_{\mathrm{adj}}\right.$ 
Table 2 Characteristics of breast and ovarian cancer cases and their corresponding controls

\begin{tabular}{|c|c|c|c|c|}
\hline Characteristics & $\begin{array}{l}\text { Breast cancer cases } \\
(n=232)\end{array}$ & $\begin{array}{l}\text { Controls for breast } \\
\text { cancer cases }(n=225)\end{array}$ & $\begin{array}{l}\text { Ovarian cancer cases } \\
(n=85)\end{array}$ & $\begin{array}{l}\text { Controls for ovarian cancer } \\
\text { cases }(n=215)\end{array}$ \\
\hline $\begin{array}{l}\text { Median year of birth } \\
\text { (range) }\end{array}$ & 1955 (1926-1974) & 1958 (1917-1985) & 1952 (1930-1971) & 1958 (1917-1985) \\
\hline $\begin{array}{l}\text { Median age of first live } \\
\text { birth (range) }\end{array}$ & $23(17-37)$ & $23(16-36)$ & $23(16-38)$ & $23(16-36)$ \\
\hline $\begin{array}{l}\text { Median age at menarche } \\
\text { (range) }\end{array}$ & $13(10-18)$ & $14(9-18)$ & $14(10-17)$ & $14(9-18)$ \\
\hline \multirow[t]{2}{*}{ Median BMI (range) } & $24(12-42)$ & $24(16-42)$ & $25(18-38)$ & $24(16-44)$ \\
\hline & $n(\%)$ & $n(\%)$ & $n(\%)$ & $n(\%)$ \\
\hline \multicolumn{5}{|l|}{ Parity } \\
\hline 0 & $17(7)$ & $26(12)$ & $7(8)$ & $23(11)$ \\
\hline 1 & $46(20)$ & 42 (19) & $14(16)$ & 40 (19) \\
\hline 2 & $110(47)$ & $96(43)$ & $43(51)$ & $96(45)$ \\
\hline 3 & $41(18)$ & $45(20)$ & $14(16)$ & 42 (19) \\
\hline 4 & $10(4)$ & $11(5)$ & $6(7)$ & $9(4)$ \\
\hline$>4$ & $8(3)$ & $5(2)$ & $1(1)$ & $5(2)$ \\
\hline \multicolumn{5}{|l|}{ Breastfeeding $^{\mathrm{a}}$} \\
\hline$\leq 12$ months & $81(38)$ & $61(31)$ & $23(29)$ & $58(30)$ \\
\hline$>12$ months & $134(62)$ & $138(69)$ & $55(71)$ & $134(70)$ \\
\hline \multicolumn{5}{|l|}{ OC use } \\
\hline$<5$ years & $221(95)$ & $207(92)$ & $84(99)$ & $197(92)$ \\
\hline$\geq 5$ years & $11(5)$ & $18(8)$ & $1(1)$ & $18(8)$ \\
\hline \multicolumn{5}{|l|}{ Smoking } \\
\hline$<4$ pack-years & $138(59)$ & $143(64)$ & $58(68)$ & $136(63)$ \\
\hline$\geq 4$ pack-years & $94(41)$ & $82(36)$ & $27(32)$ & 79 (37) \\
\hline \multicolumn{5}{|l|}{ BRCA1 mutation } \\
\hline 5382insC & $165(71)$ & $156(69)$ & $63(74)$ & 149 (69) \\
\hline C61G & $53(23)$ & $52(23)$ & $16(19)$ & 49 (23) \\
\hline 4153delA & $14(6)$ & $17(8)$ & $6(7)$ & $17(8)$ \\
\hline
\end{tabular}

$B M I$ body mass index, $O C$ oral contraceptive

a Nulliparous women were excluded

$1.56,95 \%$ CI $1.04-2.34$ and $\mathrm{OR}_{\text {adj }} 1.91,95 \%$ CI $1.01-3.60$, respectively). However, upon correction for multiple testing the significance of these effects vanished.

There were no significant differences in the allele frequencies of the AIB1 28824(CAG/CAA) $n, A R$ 171(CAG)n, CYP11A1 (AAAAT) $n, C Y P 19 A 1$ 15210(TTTA) $n, T Y M S$ 97(28)n, TGFBR1 52(GCG) $n$ and XRCC3 204(GT)n repeat polymorphisms between breast and ovarian cancer cases and their corresponding controls (Supplementary Table 3).

\section{Discussion}

We performed association studies at 29 polymorphic loci in 20 genes encoding proteins involved in DNA repair, folate metabolism, steroid hormone biosynthesis/metabolism/ signaling and cell growth to identify genetic variants that may modify $B R C A l$-associated breast and ovarian cancer risk. Numerous studies investigated polymorphisms in sporadic breast and ovarian cancer populations often yielding controversial results [4-31]; however, little is known about the effects of these polymorphisms on disease risk in women with an inherited predisposition.

A few of the polymorphisms investigated in this study have been previously analyzed for their potential risk modifying effect in $B R C A 1 / 2$ mutation carriers. An association of long AIB1 28824(CAG/CAA) $n$ alleles $(\geq 28$ and $\geq 29$ repeats) with an increased breast cancer risk was reported in two studies among BRCA1/2 mutation carriers [34, 35], which, however, was not confirmed in two other studies [36, 37] or in the present study. Similarly, conflicting results were published for $A R$ 171(CAG) $n$. One study reported an 


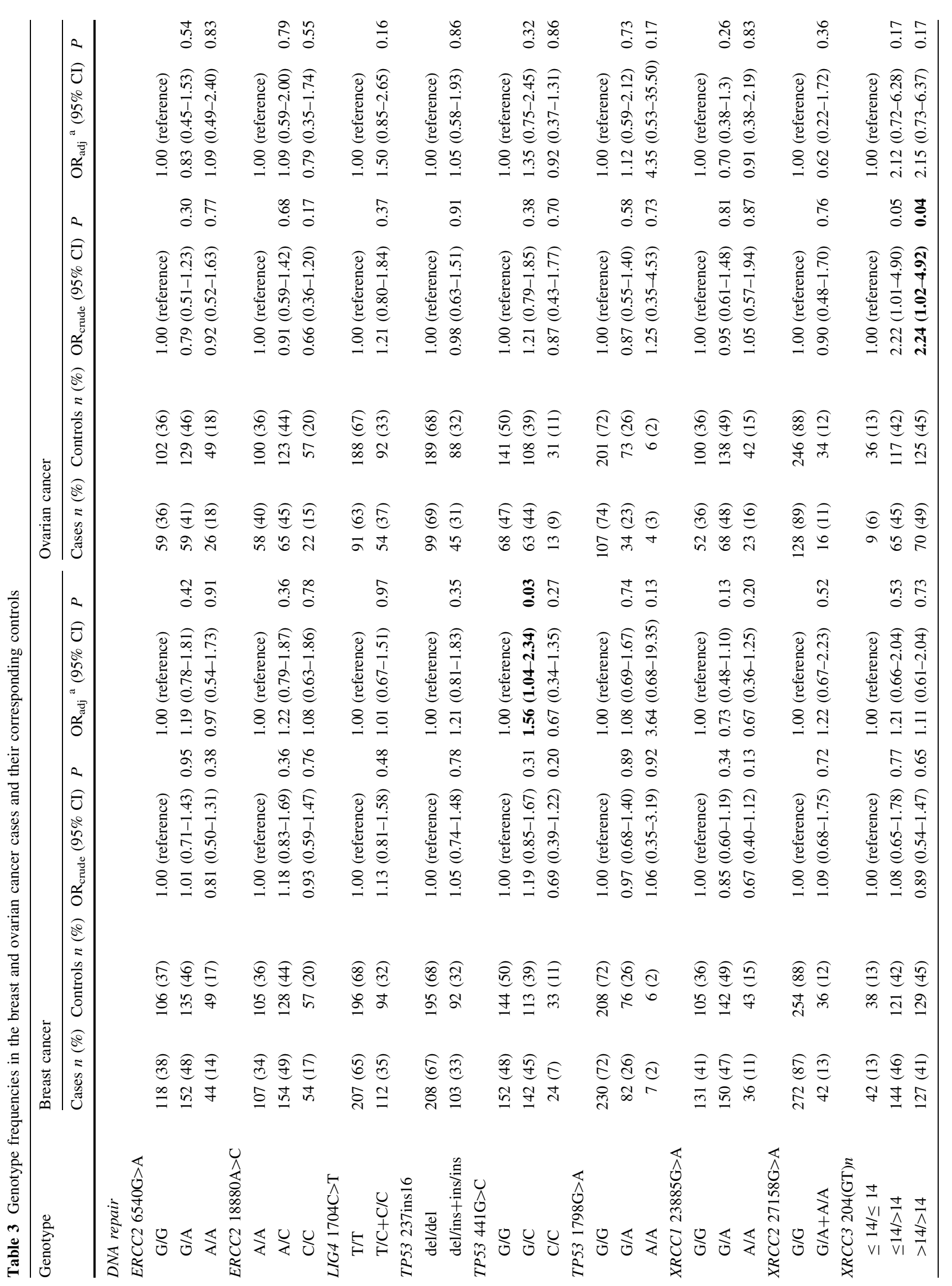




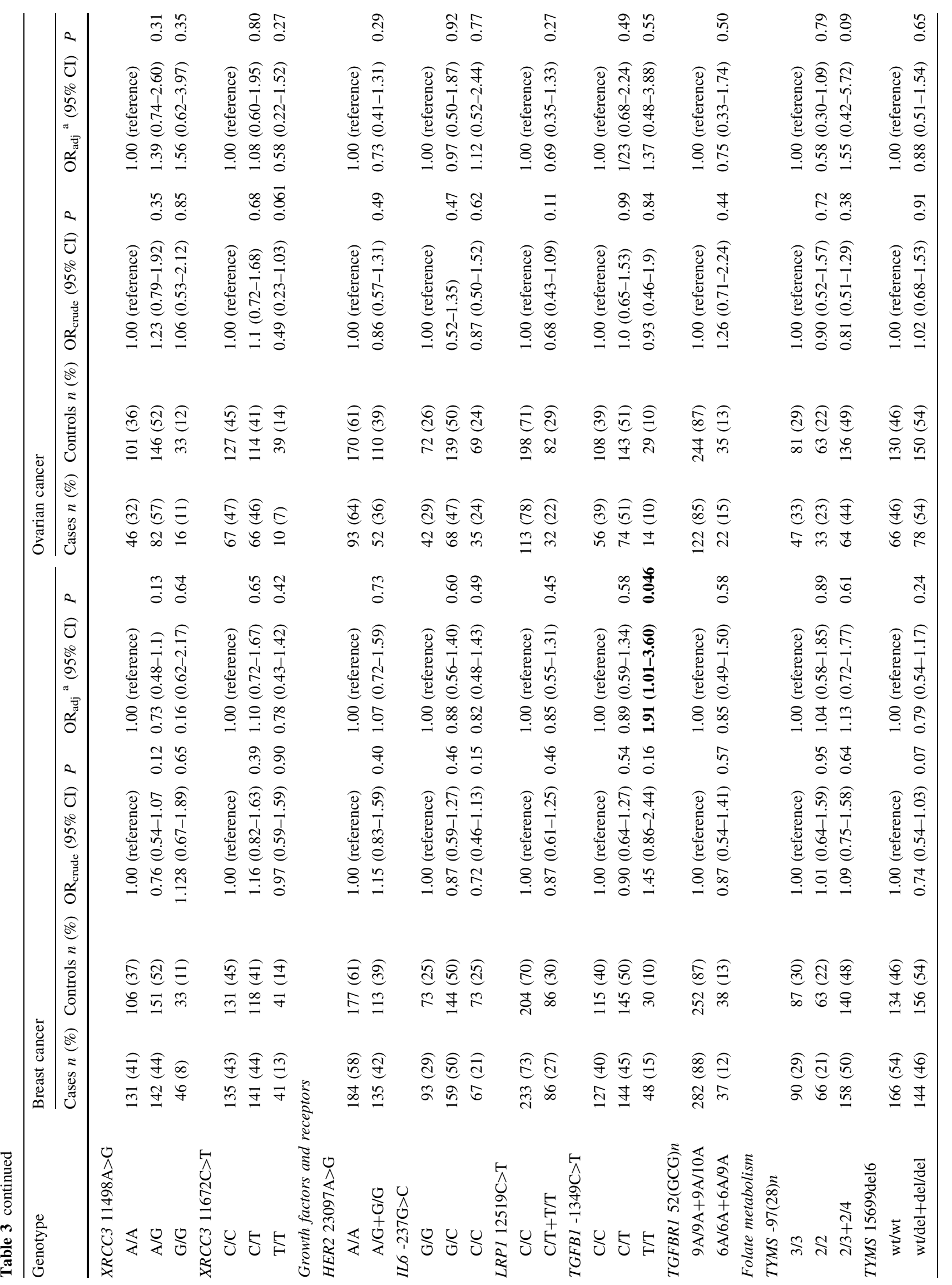




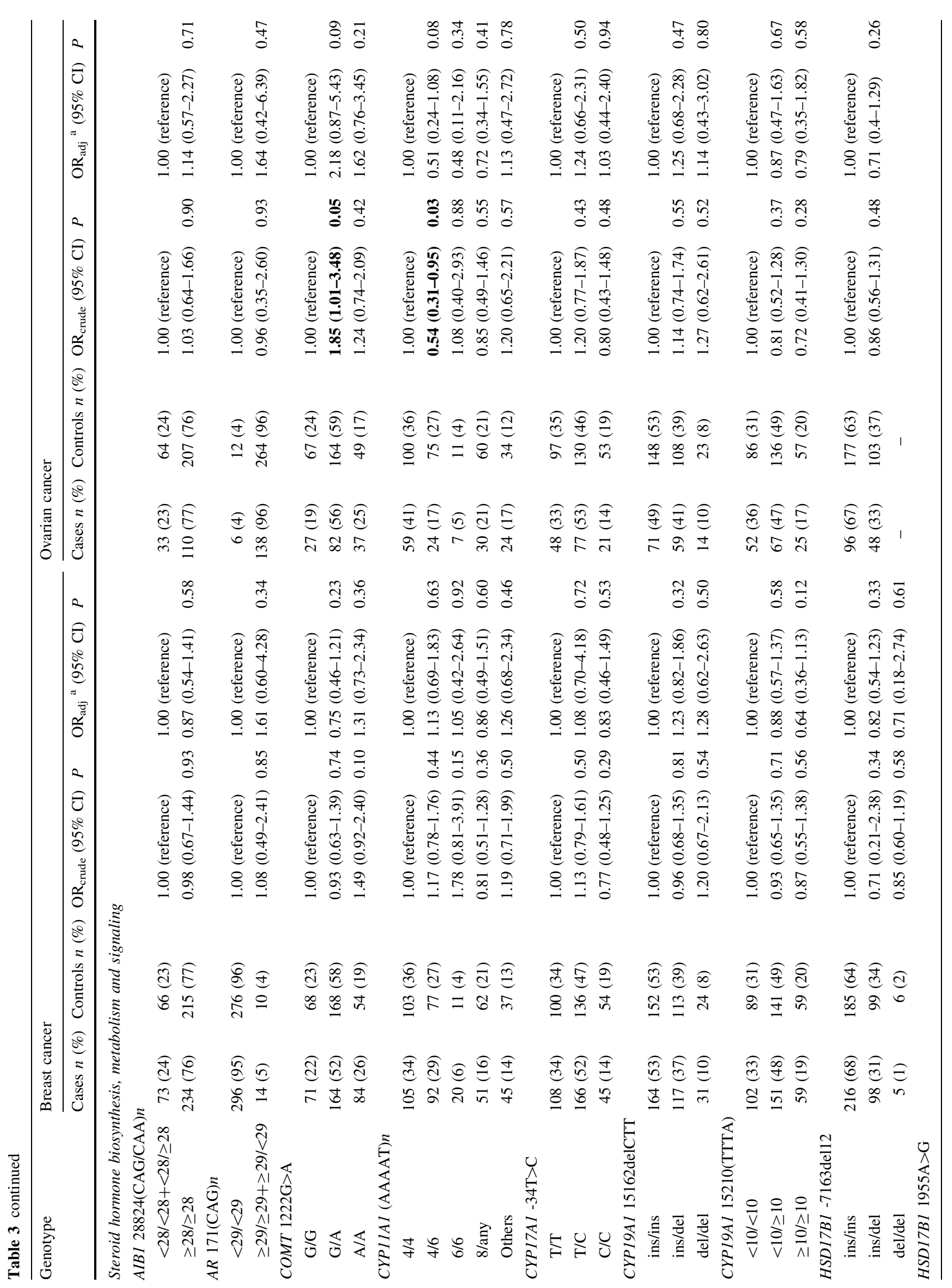




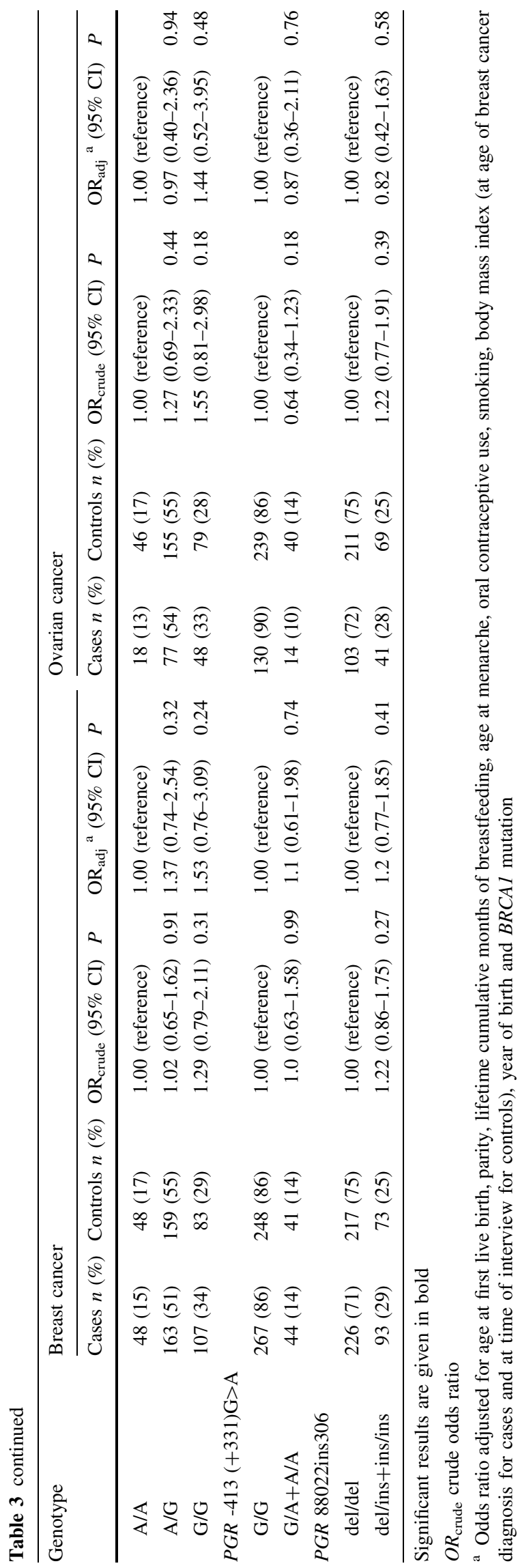

association of long $A R$ alleles ( $\geq 28, \geq 29$ and $\geq 30$ repeats) with an increased breast cancer risk among BRCAl/2 mutation carriers [38], whereas in three other studies, including the present study, this observation was not confirmed $[39,40]$. The inconsistent results may be explained by differences between these studies including size, inclusion of BRCA1, BRCA2 or both BRCA1 and BRCA2 carriers, type of $B R C A 1 / 2$ mutations or ethnicity. The latter explanation is supported by data from Kadouri et al. of significantly shorter allele lengths, on average, in 256 BRCA1/2 mutation carriers of Ashkenazi origin compared with 55 British non-Ashkenazi carriers $\left(P_{\text {trend }} 0.0007\right)$ [35]. Similar findings were observed for $A R 171$ (CAG)n, where median CAG repeat length was significantly longer in the Ashkenazi carriers compared with non-Ashkenazi carriers (23 and 21, respectively, two-sided $P=0.01$ ) and at least one allele with repeat length $\geq 28$ was found in $17 / 154(11 \%)$ of the Ashkenazi carriers, but in none of the 30 non-Ashkenazi carriers [39]. These observations suggest that differences between studied populations are an important factor in association studies on modifiers of BRCA1/2-associated breast or ovarian cancer risk.

In this study, TP53 $441 \mathrm{G}>\mathrm{C}$ and TGFB $1-1349 \mathrm{C}>\mathrm{T}$ were associated with an increased breast cancer risk in analyses adjusted for potential risk factors. However, these effects were not stable and vanished upon correction for multiple testing. We also found no association of the HER2 $23097 \mathrm{~A}>\mathrm{G}$ polymorphism with $B R C A 1$-associated breast cancer risk. This contrasts with findings from another study among Ashkenazi carriers of the three common BRCA1/2 founder mutations, which reported an association of this SNP with an increased breast cancer risk. This study however was based on a small number of 120 BRCA1/2 carriers [41].

Three polymorphisms, XRCC3 204(GT)n, COMT 1222G> A and CYP11A1 (AAAAT)n, were associated with ovarian cancer risk in the present study. These results however were also not stable and vanished once corrected for multiple testing. We also observed no association of the TP53 237ins 16 and $1798 \mathrm{G}>$ A polymorphisms with disease risk. The findings of the TP53 237ins16 are in line with those reported in a previous study [42].

In this study, patients affected by breast or ovarian cancer as well as healthy individuals were of Polish origin and all carried one of the three Polish BRCAl founder mutations. Because of the strong founder effect and the Polish population being relatively stable and ethnically homogeneous, it is ideal for association studies of risk modifying genes not influenced by $B R C A 1$ allelic or ethnic variation.

Based on statistical modeling, our study on 319 breast cancer cases, 146 ovarian cancer cases and 290 unaffected controls was sufficiently large to identify any potential association. For the breast cancer population, all 
comparisons of the reference genotype with the two genotypes had a power of at least $90 \%$ to detect an OR of at least 2.0 at the significance level of $5 \%$, except for TGFBR1 52(GCG)n and $A R$ 171(CAG)n. Those had a power larger than 80 and $60 \%$, respectively, when compared with the heterozygous genotype, and larger than $80 \%$ when compared with the homozygous variant genotype, but then only for an OR of 2.5. For the ovarian cancer population, all comparisons of the reference genotype with the two genotypes had a power of at least $80 \%$ to detect an OR of at least 2 (in about half of the polymorphisms larger than $90 \%$ ) at the significance level of $5 \%$, except for $A R$ 171(CAG)n, HSD17B1 1995A>G, XRCC2 27158G $>\mathrm{A}$, AIB1 28824(CAG/CAA)n, TGFBR1 52(GCG)n and PGR $413 \mathrm{G}>\mathrm{A}$ (power of $20,65,66,74,78$ and $78 \%$, respectively) when comparing with the heterozygous genotype, and except for TP53 1798G $>$ A, CYP11Al (AAAAT)n, TP53 441G $>$ C and CYP19A1 15162delCTT (power of 44, 66,78 and $78 \%$, respectively) when comparing with the homozygous variant genotype.

Our study has some limitations. A general selection bias may have occurred due to the use of study participants from a registry. Furthermore, due to the inclusion of incident and prevalent cases in the Polish registry, the presence of prevalent cases among our study participants may have led to a survival-bias, which is a general limitation of this type of retrospective study. However, because the frequency of BRCA1 mutation carriers is low, in the Polish population nearly $0.5 \%$ [48], it makes a recruitment of study participants from the population unrealistic. Therefore, the use of registry participants seems to be the only acceptable approach to perform this kind of study.

In summary, no association of the 29 polymorphisms in genes involved in DNA repair, folate metabolism, steroid hormone biosynthesis/metabolism/signaling and cell growth with $B R C A 1$-associated breast and ovarian cancer risks was observed. These findings indicate that these genetic variants are likely to play no or a minor role as modifiers of breast and ovarian cancer risks in Polish women carrying one of the three common BRCAl founder mutations.

Acknowledgments This work was supported by the Deutsches Krebsforschungszentrum, Heidelberg. Anna Jakubowska was a guest researcher from the Pomeranian Medical University, Szczecin, Poland supported by a fellowship from the DKFZ. Anna Jakubowska and Jacek Gronwald were supported by a Yamagiwa-Yoshida Memorial UICC International Cancer Study Grant.

\section{References}

1. Birch JM, Lindblom A, Stoppa-Lyonnet D, Bignon Y, Borg A, Hamann U, Haites N, Scott RJ, Maugard CM, Vasen H, Seitz S, Cannon-Albright SA, Schofield A, Zelada-Hedman M, The
Breast Cancer Linkage Consortium (1998) Genetic heterogeneity and penetrance analysis of the BRCA1 and BRCA2 genes in breast cancer families. Am J Hum Genet 62:676-689. doi:10.1086/301749

2. Antoniou A, Pharoah PD, Narod S, Risch HA, Eyfjord JE, Hopper JL, Loman N, Olsson H, Johannsson O, Borg A, Pasini B, Radice P, Manoukian S, Eccles DM, Tang N, Olah E, AntonCulver H, Warner E, Lubinski J, Gronwald J, Gorski B, Tulinius H, Thorlacius S, Eerola H, Nevanlinna H, Syrjäkoski K, Kallioniemi OP, Thompson D, Evans C, Peto J, Lalloo F, Evans DG, Easton DF (2003) Average risks of breast and ovarian cancer associated with BRCA1 or BRCA2 mutations detected in case Series unselected for family history: a combined analysis of 22 studies. Am J Hum Genet 72:1117-1130. doi:10.1086/375033

3. Andrieu N, Goldgar DE, Easton DF, Rookus M, Brohet R, Antoniou AC, Peock S, Evans G, Eccles D, Douglas F, Noguès C, Gauthier-Villars M, Chompret A, Van Leeuwen FE, Kluijt I, Benitez J, Arver B, Olah E, Chang-Claude J, EMBRACE, GENEPSO, GEO-HEBON, IBCCS Collaborators Group (2006) Pregnancies, breast-feeding, and breast cancer risk in the International BRCA1/2 Carrier Cohort Study (IBCCS). J Natl Cancer Inst 98:535-544

4. Kristensen VN, Borresen-Dale AL (2000) Molecular epidemiology of breast cancer: genetic variation in steroid hormone metabolism. Mutat Res 462:323-333. doi:10.1016/S1383-5742(00)00018-1

5. Thompson PA, Ambrosone C (2000) Molecular epidemiology of genetic polymorphisms in estrogen metabolizing enzymes in human breast cancer. J Natl Cancer Inst Monogr 27:125-134

6. Feigelson HS, Coetzee GA, Kolonel LN, Ross RK, Henderson BE (1997) A polymorphism in the CYP17 gene increases the risk of breast cancer. Cancer Res 57(6):1063-1065

7. Bergman-Jungeström M, Gentile M, Lundin AC, Wingren S (1999) Association between CYP17 gene polymorphism and risk of breast cancer in young women. Int J Cancer 84(4):350-353. doi:10.1002/ (SICI)1097-0215(19990820)84:4<350::AID-IJC3>3.0.CO;2-L

8. Kristensen VN, Andersen TI, Lindblom A, Erikstein B, Magnus P, Børresen-Dale AL (1998) A rare CYP19 (aromatase) variant may increase the risk of breast cancer. Pharmacogenetics 8:4348. doi:10.1097/00008571-199802000-00006

9. Baxter SW, Choong DY, Eccles DM, Campbell IG (2001) Polymorphic variation in CYP19 and the risk of breast cancer. Carcinogenesis 22:347-349. doi:10.1093/carcin/22.2.347

10. Garner EI, Stokes EE, Berkowitz RS, Mok SC, Cramer DW (2002) Polymorphisms of the estrogen-metabolizing genes CYP17 and catechol-O-methyltransferase and risk of epithelial ovarian cancer. Cancer Res 62:3058-3062

11. Xu X, Gammon MD, Zhang H, Wetmur JG, Rao M, Teitelbaum SL, Britton JA, Neugut AI, Santella RM, Chen J (2007) Polymorphisms of one-carbon-metabolizing genes and risk of breast cancer in a population-based study. Carcinogenesis 28:15041509. doi:10.1093/carcin/bgm061

12. Haiman CA, Brown M, Hankinson SE, Spiegelman D, Colditz GA, Willett WC, Kantoff PW, Hunter DJ (2002) The androgen receptor CAG repeat polymorphism and risk of breast cancer in the Nurses' Health Study. Cancer Res 62:1045-1049

13. Giguère Y, Dewailly E, Brisson J, Ayotte P, Laflamme N, Demers A, Forest VI, Dodin S, Robert J, Rousseau F (2001) Short polyglutamine tracts in the androgen receptor are protective against breast cancer in the general population. Cancer Res 61:5869-5874

14. Dunning AM, Healey CS, Pharoah PD, Foster NA, Lipscombe JM, Redman KL, Easton DF, Day NE, Ponder BA (1998) No association between a polymorphism in the steroid metabolism gene CYP17 and risk of breast cancer. Br J Cancer 77:2045-2047

15. Ye Z, Parry JM (2002) The CYP17 MspA1 polymorphism and breast cancer risk: a meta-analysis. Mutagenesis 17:119-126. doi:10.1093/mutage/17.2.119 
16. Healey CS, Dunning AM, Durocher F, Teare D, Pharoah PD, Luben RN, Easton DF, Ponder BA (2000) Polymorphisms in the human aromatase cytochrome P450 gene (CYP19) and breast cancer risk. Carcinogenesis 21:189-193. doi:10.1093/carcin/ 21.2.189

17. Wedrén S, Rudqvist TR, Granath F, Weiderpass E, IngelmanSundberg M, Persson I, Magnusson C (2003) Catechol-O-methyltransferase gene polymorphism and post-menopausal breast cancer risk. Carcinogenesis 24:681-687. doi:10.1093/carcin/bgg022

18. Goodman JE, Lavigne JA, Hengstler JG, Tanner B, Helzlsouer $\mathrm{KJ}$, Yager JD (2000) Catechol- $O$-methyltransferase polymorphism is not associated with ovarian cancer risk. Cancer Epidemiol Biomarkers Prev 9:1373-1376

19. Spurdle AB, Dite GS, Chen X, Mayne CJ, Southey MC, Batten LE, Chy H, Trute L, McCredie MR, Giles GG, Armes J, Venter DJ, Hopper JL, Chenevix-Trench G (1999) Androgen receptor exon 1 CAG repeat length and breast cancer in women before age forty years. J Natl Cancer Inst 91:961-966. doi:10.1093/jnci/91.11.961

20. Menin C, Banna GL, De Salvo G, Lazzarotto V, De Nicolo A, Agata S, Montagna M, Sordi G, Nicoletto O, Chieco-Bianchi L, D'Andrea E (2001) Lack of association between androgen receptor CAG polymorphism and familial breast/ovarian cancer. Cancer Lett 168:31-36. doi:10.1016/S0304-3835(01)00473-6

21. Haiman CA, Hankinson SE, Spiegelman D, Colditz GA, Willett WC, Speizer FE, Brown M, Hunter DJ (2000) Polymorphic repeat in AIB1 does not alter breast cancer risk. Breast Cancer Res 2:378-385. doi:10.1186/bcr82

22. Goode EL, Ulrich CM, Potter JD (2002) Polymorphisms in DNA repair genes and associations with cancer risk. Cancer Epidemiol Biomarkers Prev 11:1513-1530

23. Kuschel B, Auranen A, McBride S, Novik KL, Antoniou A, Lipscombe JM, Day NE, Easton DF, Ponder BA, Pharoah PD, Dunning A (2002) Variants in DNA double-strand break repair genes and breast cancer susceptibility. Hum Mol Genet 11:13991407. doi: $10.1093 / \mathrm{hmg} / 11.12 .1399$

24. Mitrunen K, Hirvonen A (2003) Molecular epidemiology of sporadic breast cancer. The role of polymorphic genes involved in oestrogen biosynthesis and metabolism. Mutat Res 544:9-41. doi:10.1016/S1383-5742(03)00016-4

25. Levine DA, Boyd J (2001) The androgen receptor and genetic susceptibility to ovarian cancer: results from a case series. Cancer Res 61:908-911

26. Zheng W, Gao YT, Shu XO, Wen W, Cai Q, Dai Q, Smith JR (2004) Population-based case-control study of CYP11A gene polymorphism and breast cancer risk. Cancer Epidemiol Biomarkers Prev 13:709-714

27. Millikan RC, Hummer AJ, Wolff MS, Hishida A, Begg CB (2005) HER2 codon 655 polymorphism and breast cancer: results from kin-cohort and case-control analyses. Breast Cancer Res Treat 89:309-312. doi:10.1007/s10549-004-2171-5

28. Hefler LA, Grimm C, Lantzsch T, Lampe D, Leodolter S, Koelbl H, Heinze G, Reinthaller A, Tong-Cacsire D, Tempfer C, Zeillinger R (2005) Interleukin-1 and interleukin-6 gene polymorphisms and the risk of breast cancer in caucasian women. Clin Cancer Res 11:5718-5721. doi:10.1158/1078-0432.CCR-05-0001

29. DeMichele A, Martin AM, Mick R, Gor P, Wray L, Klein-Cabral M, Athanasiadis G, Colligan T, Stadtmauer E, Weber B (2003) Interleukin-6 - $174 \mathrm{G} \rightarrow \mathrm{C}$ polymorphism is associated with improved outcome in high-risk breast cancer. Cancer Res 63:80518056

30. Benes P, Jurajda M, Zaloudík J, Izakovicová-Hollá L, Vácha J (2003) C766T low-density lipoprotein receptor-related protein 1 (LRP1) gene polymorphism and susceptibility to breast cancer. Breast Cancer Res 5:R77-R81. doi:10.1186/bcr591

31. Dunning AM, Ellis PD, McBride S, Kirschenlohr HL, Healey CS, Kemp PR, Luben RN, Chang-Claude J, Mannermaa A, Kataja V,
Pharoah PD, Easton DF, Ponder BA, Metcalfe JC (2003) A transforming growth factor beta1 signal peptide variant increases secretion in vitro and is associated with increased incidence of invasive breast cancer. Cancer Res 63:2610-2615

32. Song B, Margolin S, Skoglund J, Zhou X, Rantala J, Picelli S, Werelius B, Lindblom A (2007) TGFBR1(*)6A and Int7G24A variants of transforming growth factor-beta receptor 1 in Swedish familial and sporadic breast cancer. Br J Cancer 97:1175-1179. doi:10.1038/sj.bjc.6603961

33. Baxter SW, Choong DY, Eccles DM, Campbell IG (2002) Transforming growth factor beta receptor 1 polyalanine polymorphism and exon 5 mutation analysis in breast and ovarian cancer. Cancer Epidemiol Biomarkers Prev 11:211-214

34. Rebbeck TR, Wang Y, Kantoff PW, Krithivas K, Neuhausen SL, Godwin AK, Daly MB, Narod SA, Brunet JS, Vesprini D, Garber JE, Lynch HT, Weber BL, Brown M (2001) Modification of BRCA1- and BRCA2-associated breast cancer risk by AIB1 genotype and reproductive history. Cancer Res 61:5420-5424

35. Kadouri L, Kote-Jarai Z, Easton DF, Hubert A, Hamoudi R, Glaser B, Abeliovich D, Peretz T, Eeles RA (2004) Polyglutamine repeat length in the AIB1 gene modifies breast cancer susceptibility in BRCA1 carriers. Int J Cancer 108:399-403. doi:10.1002/ijc. 11531

36. Hughes DJ, Ginolhac SM, Coupier I, Barjhoux L, Gaborieau V, Bressac-de-Paillerets B, Chompret A, Bignon YJ, Uhrhammer N, Lasset C, Giraud S, Sobol H, Hardouin A, Berthet P, Peyrat JP, Fournier J, Nogues C, Lidereau R, Muller D, Fricker JP, Longy M, Toulas C, Guimbaud R, Yannoukakos D, Mazoyer S, Lynch HT, Lenoir GM, Goldgar DE, Stoppa-Lyonnet D, Sinilnikova OM (2005) Breast cancer risk in BRCA1 and BRCA2 mutation carriers and polyglutamine repeat length in the AIB1 gene. Int $\mathbf{J}$ Cancer 117:230-233. doi:10.1002/ijc.21176

37. Spurdle AB, Antoniou AC, Kelemen L, Holland H, Peock S, Cook MR, Smith PL, Greene MH, Simard J, Plourde M, Southey MC, Godwin AK, Beck J, Miron A, Daly MB, Santella RM, Hopper JL, John EM, Andrulis IL, Durocher F, Struewing JP, Easton DF, Chenevix-Trench G, Australian Breast Cancer Family Study Australian Jewish Breast Cancer Study, Breast Cancer Family Registry, Interdisciplinary Health Research International Team on Breast Cancer Susceptibility, The Kathleen Cunningham Foundation Consortium for Research into Familial Breast Cancer, Epidemiological Study of Familial Breast Cancer Study Collaborators (2006) The AIB1 polyglutamine repeat does not modify breast cancer risk in BRCA1 and BRCA2 mutation carriers. Cancer Epidemiol Biomarkers Prev 15(1):76-79. doi:10.1158/1055-9965.EPI-05-0709

38. Rebbeck TR, Kantoff PW, Krithivas K, Neuhausen S, Blackwood MA, Godwin AK, Daly MB, Narod SA, Garber JE, Lynch HT, Weber BL, Brown M (1999) Modification of BRCA1-associated breast cancer risk by the polymorphic androgen-receptor CAG repeat. Am J Hum Genet 64:1371-1377. doi:10.1086/302366

39. Kadouri L, Easton DF, Edwards S, Hubert A, Kote-Jarai Z, Glaser B, Durocher F, Abeliovich D, Peretz T, Eeles RA (2001) $\mathrm{CAG}$ and GGC repeat polymorphisms in the androgen receptor gene and breast cancer susceptibility in BRCA1/2 carriers and non-carriers. Br J Cancer 85:36-40. doi:10.1054/bjoc.2001.1777

40. Spurdle AB, Antoniou AC, Duffy DL, Pandeya N, Kelemen L, Chen X, Peock S, Cook MR, Smith PL, Purdie DM, Newman B, Dite GS, Apicella C, Southey MC, Giles GG, Hopper JL, Chenevix-Trench G, Easton DF EMBRACE, Collaborators Study (2005) The androgen receptor CAG repeat polymorphism and modification of breast cancer risk in BRCA1 and BRCA2 mutation carriers. Breast Cancer Res 7:R176-R183. doi:10.1186/ bcr971

41. Rutter JL, Chatterjee N, Wacholder S, Struewing J (2003) The HER2 I655V polymorphism and breast cancer risk in Ashkenazim. 
Epidemiology 14:694-700. doi:10.1097/01.ede.0000083227. $74669.7 \mathrm{~b}$

42. Wang-Gohrke S, Weikel W, Risch H, Vesprini D, Abrahamson J, Lerman C, Godwin A, Moslehi R, Olipade O, Brunet JS, Stickeler E, Kieback DG, Kreienberg R, Weber B, Narod SA, Runnebaum IB (1999) Intron variants of the p53 gene are associated with increased risk for ovarian cancer but not in carriers of BRCA1 or BRCA2 germline mutations. Br J Cancer 81:179-183. doi:10.1038/sj.bjc.6690669

43. Górski B, Byrski T, Huzarski T, Jakubowska A, Menkiszak J, Gronwald J, Pluzańska A, Bebenek M, Fischer-Maliszewska L, Grzybowska E, Narod SA, Lubiński J (2000) Founder mutations in the BRCA1 gene in Polish families with breast-ovarian cancer. Am J Hum Genet 66:1963-1968. doi:10.1086/302922

44. Górski B, Jakubowska A, Huzarski T, Byrski T, Gronwald J, Grzybowska E, Mackiewicz A, Stawicka M, Bebenek M, Sorokin D, Fiszer-Maliszewska $Ł$, Haus O, Janiszewska H, Niepsuj S, Góźdź S, Zaremba L, Posmyk M, Płuzańska M, Kilar E, Czudowska D, Waśko B, Miturski R, Kowalczyk JR, Urbański K, Szwiec M, Koc J, Debniak B, Rozmiarek A, Debniak T, Cybulski C, Kowalska E, Tołoczko-Grabarek A, Zajaczek S, Menkiszak J, Medrek K, Masojć B, Mierzejewski M, Narod SA, Lubiński J (2004) A high proportion of founder BRCA1 mutations in Polish breast cancer families. Int J Cancer 110:683-686. doi:10.1002/ ijc. 20162

45. Lahiri DK, Schnabel B (1993) DNA isolation by a rapid method from human blood samples: effects of $\mathrm{MgCl} 2$, EDTA, storage time, and temperature on DNA yield and quality. Biochem Genet 31:321-328. doi:10.1007/BF02401826

46. Justenhoven C, Hamann U, Schubert F, Zapatka M, Pierl CB, Rabstein S, Selinski S, Mueller T, Ickstadt K, Gilbert M, Ko YD, Baisch C, Pesch B, Harth V, Bolt HM, Vollmert C, Illig T, Eils R, Dippon J, Brauch H (2008) Breast cancer: a candidate gene approach across the estrogen metabolic pathway. Breast Cancer Res Treat 108:137-149. doi:10.1007/s10549-007-9586-8

47. Hothorn T, Lausen B (2003) On the exact distribution of maximally selected rank statistics. Comput Stat Data Anal 43:121

48. Gorski B, Cybulski C, Huzarski T, Byrski T, Gronwald J, Jakubowska A, Stawicka M, Gozdecka-Grodecka S, Szwiec M, Urbanski K, Mitus J, Marczyk E, Dziuba J, Wandzel P, Surdyka D, Haus O, Janiszewska H, Debniak T, Toloczko-Grabarek A, Medrek K, Masojc B, Mierzejewski M, Kowalska E, Narod SA, Lubinski J (2005) Breast cancer predisposing alleles in Poland. Breast Cancer Res Treat 92:19-24. doi:10.1007/s10549-0051409-1 